\title{
Evaluation of antimicrobial and antibiofilm activities of stingless bee Trigona honey (Malaysia) against Streptococcus pneumoniae
}

\author{
Mohammad A. Al-kafaween ${ }^{1}$, \\ Hamid A. Nagi Al-Jamal ${ }^{1}$, Abu Bakar Mohd Hilmi ${ }^{1}$
}

\section{Abstract}

Background: The study aims to evaluate the antibacterial and antibiofilm activities of Trigona honey (TH) in Malaysia against Streptococcus pneumoniae.

Methods: The effect of TH on S. pneumoniae investigated using agar well diffusion, MIC, MBC, biofilm formation and RT-qPCR.

Results: TH sample showed the larger zones of inhibition against $S$. pneumoniae, $22.2 \pm 0.4$ at $100 \%$ concentration. $\mathrm{TH}$ possessed the lowest MIC, MBC, $\mathrm{MIC}_{50}$ and $\mathrm{MIC}_{90}$ against S. pneumoniae, 25\%, $30 \%, 12.5 \%$ and $25 \%(\mathrm{w} / \mathrm{v})$ respectively. TH permeated established biofilms of $S$. pneumoniae, resulting in significant decreased the cells from the biofilm. RT-qPCR revealed that the expression of genes amiF, fts $Y$, mvas, pnpA, arg $G$, mvd1, purN, miaA and pbp2a were upregulated. While, glcK, marR, prmA and ccpA were downregulated after exposure to honey.

Conclusion: Trigona honey demonstrated the highest antibacterial activity against S. pneumoniae at $100 \%$ of honey concentration. It has also shown that biofilm formation, and growth and survival of bacteria in biofilms is a complex process and require gene expression.

\section{Keywords}

Biofilm; Gene expression, Trigona honey (TH); Streptococcus pneumoniae.
1 Faculty of Health Sciences, Universiti Sultan Zainal Abidin, Terengganu, Malaysia.

\section{Contact information:}

Mohammad A. Al-kafaween \& Hamid A. Nagi Al-Jamal

झ mohammadalkafaween25@yahoo.com aljamalhamid@unisza.edu.my 


\section{Introduction}

Streptococcus pneumoniae, an important human pathogen, is the most common cause for pneumonia, meningitis, and otitis media [1]. Pneumococcal infections cause death for more than 1 million children in the world per year, especially in developing countries [2]. Colonization of the nasopharyngeal niche is a commonality shared among $S$. pneumoniae, S. pyogenes, and S. aureus [3]. Biofilm pneumococci display gene expression profiles similar to those of bacteria isolated from the lungs of mice; these profiles are distinct from planktonic bacteria isolated from either blood or culture media [4]. Studies by Muñoz-Elías, (2008), Parker, (2009) and Trappetti, (2011) indicate that the genes required for robust biofilm formation in vitro are important for nasopharyngeal colonization and, in some instances, progression towards lung disease. In contrast, studies by Tapianen, (2008), Camilli, (2008) Lizcano, (2008) and Sanchez, (2008) reported no correlation between the ability of isolates to form robust biofilms in vitro and their virulence potential in humans and mice. Furthermore, Lizcano, (2008) reported that the ability to form early biofilms in vitro does not reflect virulence potential [5]. Antibiotic resistance is a serious problem worldwide, and it has made the search for new antimicrobial compounds more important [6]. Honey has been used as a traditional medicine for centuries [7]. Many in vitro studies have revealed antimicrobial activity of different honeys against a wide range of skin colonizing and food-borne bacterial species, including antibiotic-resistant bacteria. Honey has beneficial actions against wound infections also in vivo [8], and licensed honey products are widely used in wound care [9]. Several properties in honey contribute to its antimicrobial activity. High osmolarity, low $\mathrm{pH}$, and hydrogen peroxide are the main antimicrobial factors [10]. Also phenolic compounds may contribute to antimicrobial activity [11]. Many studies on antimicrobial activity of honey have been conducted in non-European countries [12]. However, it has been found that other honeys with different floral backgrounds exhibit equivalent inhibitory activity [13]. It is thus reasonable to search for new antimicrobial honey candidates from different parts of the world. TH is produced by stingless bees without stings grown in uncultivated bushland in Malaysia and Indonesia. TH is generally brighter in appearance than ordinary forest honey and has a distinctive "bush" taste, i.e., a mixture of sweet and sour with a hint of fruity taste [14]. It has been reported that honey has more than 100 distinct compounds with different biological functions [15], the main antibacterial compound in most types of honey is hydrogen peroxide [16]. However, perhaps the antibacterial activity of $\mathrm{TH}$ is due to phenolic compounds [17]. These compounds have non-sticky properties that could be used to control bacterial growth and biofilm formation [18]. In Malaysia, there are less available data on the therapeutic values of stingless bee Trigona honey against S. pneumoniae, especially at cellular and molecular levels, particularly on the virulence genes by using biofilm model. However, in this study, we tested the antibacterial and antibiofilm activities of TH against the important human pathogens $S$. pneumoniae.

\section{Materials and Methods}

\section{Bacterial strains and culture conditions}

S. pneumoniae (ATCC 49619) was purchased from American type tissue culture (ATCC) and used throughout this study. The bacteria were grown routinely in TSB or on $\mathrm{BHI}$ agar plates supplemented with $5 \%(\mathrm{v} / \mathrm{v})$ sheep blood at $37^{\circ} \mathrm{C}$ in $5 \% \mathrm{CO}_{2}$.

\section{Honey samples}

Commercial Trigona honey (TH) samples were purchased for the present study from Kelantan a state in East Coast of Peninsula Malaysia. Stock samples 
$100 \%$ were stored in the dark bottles, labelled accordingly and stored at room temperature away from light source. Then, honey samples have been prepared freshly for each experiment and syringe filter (pore size $0.45 \mu \mathrm{m}$, diameter $25 \mathrm{~mm}$ ) was used in this study [19]. To ascertain the security of the purchased product, honey was presented to the bee hunters based on their geographical hunting area to identify the purity, reliability, and quality of the honey.

\section{Agar well diffusion assay}

Sterile distilled water was used to dilute $\mathrm{TH}$ to achieve 10\%, 25\%, 50\%, and 75\%, (w/v) concentration of honey. A 4-5 colonies of $S$. pneumoniae were aseptically picked from the fresh culture plate using sterile cotton swab and then were suspended into $10 \mathrm{~mL}$ of saline solution and the inoculum was adjusted to be equal to $0.5 \mathrm{McFarland}$ standard $\left(1 \times 10^{8} \mathrm{CFU} / \mathrm{ml}\right)$. A sterile cotton swab was then dipped into the bacterial suspension and streaked over the entire surface of plate for three times to ensure distribution. A sterile $9 \mathrm{~mm}$ cork borer (Fisher Scientific, UK) was used to create six wells of agar plate. The wells of agar plate were labelled and were added with $100 \mu \mathrm{L}$ of the five different honey concentration; 10\%, 25\%, 50\%, 75\%, and $100 \%(w / v)$. The well with distilled water was used as a negative control. The agar plates were then incubated at $37{ }^{\circ} \mathrm{C}$ for 24 hours. Ampicillin $(10 \mu \mathrm{g})$, ciprofloxacin $(5 \mu \mathrm{g})$ and tetracycline $(30 \mu \mathrm{g})$ were included to ascertain the reproducibility and reliability of the assay and the bacterial resistant profiles. Digital venire calliper was used to measure the zones of inhibition [20-21]. The assay was carried out in triplicate

\section{Minimum inhibitory concentration}

The MIC test was determined by using broth micro dilution method. Working bacteria culture was prepared as previously described, adjusted to be equal to $0.5 \mathrm{McFarland}$ standard $\left(1 \times 10^{8} \mathrm{CFU} / \mathrm{ml}\right)$ [20-21].
The concentrations of $\mathrm{TH} ; 50 \%, 30 \%, 25 \%, 20 \%$, $12.5 \%, 10 \%, 6.3 \%, 5 \%, 3.1 \%$ and $1.6 \%(\mathrm{w} / \mathrm{v})$ were freshly prepared for MIC. Initially, column number 1 was filled with $100 \mu \mathrm{l}$ of inoculums with $50 \%$ concentration of honey, and the consecutive columns 2 to 10 were filled with its corresponding concentration $(30 \%, 25 \%, 20 \%, 12.5 \%, 10 \%, 6.3 \%, 5 \%$, $3.1 \%$ and $1.6 \%(\mathrm{w} / \mathrm{v})$ respectively). Column number 11 was filled with $100 \mu$ l of honey as a corresponding negative control, and column number 12 was filled with $100 \mu \mathrm{l}$ of inoculum as a bacterial growth control. The plates were incubated at $37^{\circ} \mathrm{C}$ for 24 hours. After 24 hours, visually inspection was done. MIC value was identify by turbidity in the wells and were compared to the positive and negative controls [21-23]. Absorbance was measured by using the microtiter plate reader (Tecan Infinite 200 PRO, Austria) at $590 \mathrm{~nm}$. The $\mathrm{MIC}_{50}$ and $\mathrm{MIC}_{90}$ was determined by using the following formula:

Growth inhibition=

1-OD of bacterial growth control - OD of the test well $\times 100$

OD of bacterial growth control

\section{Minimum bactericidal concentration}

Minimum Bactericidal Concentration (MBC) was conducted using wells that appeared to have no growth (no turbidity) by visual inspection and were streaked onto nutrient agar plates using sterile $100 \mu \mathrm{l}$ loops. A sterile wire loop was gently and aseptically dipped into the non-turbidity selected wells before the bacteria were cultured on agar plate. The plates were labelled and incubated at $37^{\circ} \mathrm{C}$ for 24 hours. Plate free of any bacterial growth was recorded as the MBC value [21].

\section{Biofilm disruption}

To determine whether TH affected biofilm biomass by facilitating the dissociation of adherent cells from the biofilm. Bacteria were grown in 96-well plate (Fisher Scientific, UK) for 24 hours at $37^{\circ} \mathrm{C}$. After incubation, the liquid was discarded from each well, 
biofilms were washed thrice with PBS to remove any planktonic cells, and TH over a range of concentrations [0, 10, 20 and $40 \%(\mathrm{w} / \mathrm{v})$, respectively] was added to the 24 hours established biofilms (Biofilms were tested by tube method and quantitative spectrophotometric method). Following the application of honey, bacterial cultures in the microtiter plate were incubated for a further 3 hours at $37^{\circ} \mathrm{C}$ as above and samples of the liquid above the biofilm were collected at 30 min intervals and optical density was measured at 590nm using microplate reader [24].

\section{Extraction of RNA from S. pneumoniae biofilms for RT-qPCR}

Large scale, static biofilms of $S$. pneumoniae were grown in duplicate in $10 \mathrm{ml}$ TSB medium (with $20 \%$ honey for the 'treated' biofilms) in sterile petri dishes for 24 hours at $37^{\circ} \mathrm{C}$, as for the small-scale biofilms. The liquid was aspirated and the biofilm was scraped from the surface of the Petri dish using a sterile cell scraper. Biofilms were resuspended in $500 \mu \mathrm{l} \mathrm{PBS}$ and vortexed for $1 \mathrm{~min}$ to break up cell aggregates. Honey-treated and untreated cell suspensions were equilibrated (to approximately $2.0 \times 10^{8} \mathrm{CFU} / \mathrm{ml}$ ) prior to treatment with mutanolysin $5 \mu$ and lysozyme $5 \mu$ for 15 minutes at 37 ${ }^{\circ} \mathrm{C}$. RNA extraction was carried out using the SV total RNA extraction kit (Promega, UK) according to the manufacturer's instructions. RNA quantification was performed by Bioanalyzer 2100 (Agilent, USA). CDNA synthesis was carried out using a Reverse Transcriptase kit (Promega, UK) according to the manufacturer's instructions. Briefly, tailing of RNA with a random primer was performed at $70^{\circ} \mathrm{C}$ for 5 minutes, annealing at $25^{\circ} \mathrm{C}$ for 5 minutes, extension at $37^{\circ} \mathrm{C}$ for 1 hours and inactivation of samples at $70^{\circ} \mathrm{C}$ for 15 minutes. Primers of $S$. pneumoniae were retrieved from previous studies as shown in Table 1 \{Yadav, 2012 \#86\}. Lyophilised and desalted oligonucleotides were reconstituted using sterile ultrapure water. Oligonucleotides of
S. pneumoniae were optimised and the efficiencies were tested prior to gene expression analysis. Optimal primers concentration were determined by qPCR of $S$. pneumoniae CDNA with a range of primer concentrations (100 nM to $400 \mathrm{nM}$ ). Densitometry was performed using the Applied Biosystems Step One Software V2.3. To determine the level of relative gene expression of $S$. pneumoniae samples, a modified $2^{-\Delta \Delta} \mathrm{Ct}$ method was used. All reactions were carried out in triplicate, and the expression of genes was analysed with reference to the expression of the housekeeping gene [2526]. (Table 1)

\section{Statistical Analysis}

Data was expressed as mean \pm standard deviation. Independent student t-test from (SPSS version 20, 2020) was used to compare between honey-treated and control groups. The significant was set at $P<0.05$.

\section{Results}

Inhibition of planktonic S. pneumoniae by TH As shown in Table 2, agar well-diffusion assay shows the zone of inhibition for S. pneumoniae after treated with $100 \%, 75 \%, 50 \%, 25 \%$ and $10 \%(\mathrm{w} / \mathrm{v})$ concentration of $\mathrm{TH}$. TH exhibits greater inhibition on S. pneumoniae cultures The MIC of TH against S. pneumoniae was found to be $25 \%(\mathrm{w} / \mathrm{v})$ and the $\mathrm{MBC}$ was found to be $30 \%(\mathrm{w} / \mathrm{v})$. The $\mathrm{MIC}_{50}$ was found to be $12.5 \%(\mathrm{w} / \mathrm{v})$ concentration of $\mathrm{TH}$ and $\mathrm{MIC}_{90}$ was found to be $25 \%(\mathrm{w} / \mathrm{v})$ of TH against $S$. pneumoniae as shown in Figure 1 \& Table 2.

\section{S. pneumoniae biofilm development are inhi-} bited by sublethal concentrations of TH When biofilms of $S$. pneumoniae were initiated in the presence of $10 \%, 20 \%$ and $40 \%(\mathrm{w} / \mathrm{v}) \mathrm{TH}, \mathrm{a}$ statistically significant reduction in biomass was observed in each case. As shown in Figure 2, a reduc- 
Table 1. Gene specific primers of $S$. pneumoniae used for RT-qPCR analysis.

\begin{tabular}{|c|c|c|c|}
\hline \multirow{2}{*}{ Gene name } & Forward primer sequences & Reverse primer sequences & Amplicon size \\
\hline & $5^{\prime} \rightarrow 3^{\prime}$ & $5^{\prime} \rightarrow 3^{\prime}$ & bp \\
\hline amiF & GCTGAAAGCAAGGCTTGAGTA & ACTTGTCGGTTGTTCGCTT & 130 \\
\hline$f t s Y$ & TCGAAAATTCTTTGGCCTGT & ATCAAACGTGTTGTGCCAA & 97 \\
\hline mvas & ATAGGGCAGTTCGTTGGTTG & AGTGGAGCTGTGGCTGAGTT & 103 \\
\hline pnpA & TCGAGAAATTTGGTGCCTTT & ACGAGTCCAAGCCATCTCAG & 80 \\
\hline $\arg G$ & AAATCGCTTGGTTGGGATTA & CACAAGCGTCAAGTCCTCAA & 100 \\
\hline mvd1 & GGCTATGCATGCTACGACAA & CGAACAAAGTCCATAGCCTCA & 84 \\
\hline purN & TCCAGCCTACTTGCCAGAAT & CCAGTGAATGGTCACACCAG & 91 \\
\hline $\operatorname{mia} A$ & GAGCGTATCAACCACCGAGT & TAGGGGAATGGTCAAACAGC & 82 \\
\hline pbp2a & GGTGCAATTCCATTTTGCTT & CGGTGCAGCTCATGTCTTTA & 105 \\
\hline glck & TGAAAAAGGAGAATATGATGAGTCAA & TGCAAATTTGATAGAAGTTCCAC & 71 \\
\hline marR & TGACCCCAAACAAAGAAGAC & CCGCAATTTCCTTGTTGGTA & 84 \\
\hline prmA & ATGGAAACATGGCAAGAGTT & GCTCCCAGCTCAATCAAGAG & 83 \\
\hline ссрA & GACAGGAAAAGGAATGAATGC & GGAAACACCTGCTTCACGAG & 70 \\
\hline$g y r B^{*}$ & GATTTGGCGCAGAATTTGAT & GTACGAATGTGGGCTCCATC & 91 \\
\hline
\end{tabular}

*: gyrB was used as a reference gene.

Table 2. Determination of inhibition zone (mm).

\begin{tabular}{|l|c|c|c|c|c|}
\hline \multirow{2}{*}{ Test organism } & \multicolumn{5}{|c|}{ Concentration of TH } \\
\cline { 2 - 6 } & $100 \%$ & $75 \%$ & $50 \%$ & $25 \%$ & $10 \%$ \\
\hline S. pneumoniae & $22.2 \pm 0.4$ & $19.1 \pm 0.4$ & $16.6 \pm 0.3$ & $9.3 \pm 0.6$ & $00.0 \pm 0.0$ \\
\hline
\end{tabular}

Figure 1: Percentage of bacteria growth inhibition by Malaysian $\mathrm{TH}$.

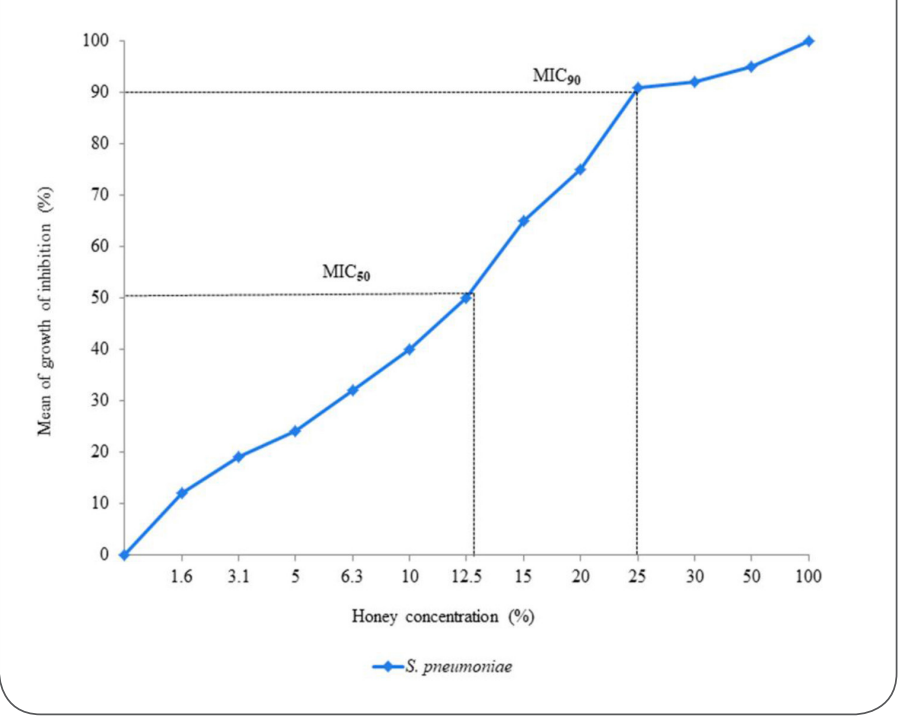

Figure 2: The disruption of biofilm development using $\mathrm{TH}$.

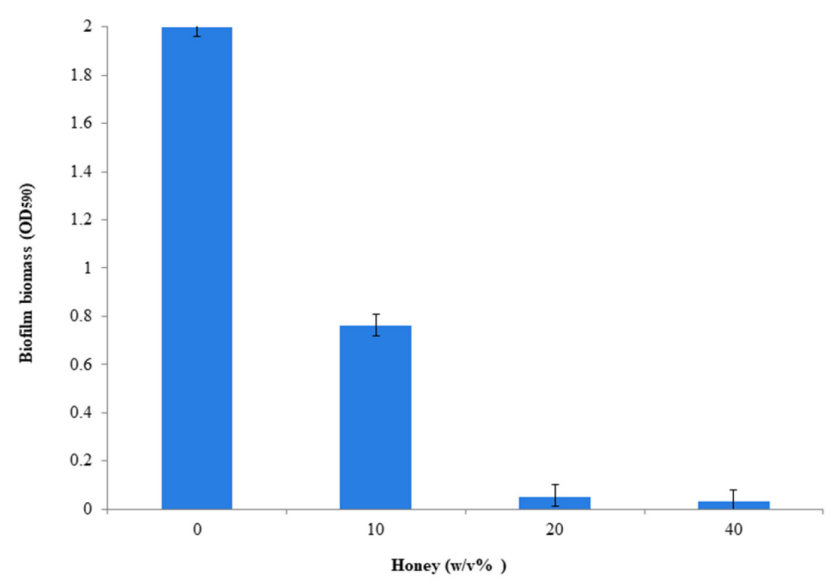

Biofilms of S. pneumoniae were grown for $24 \mathrm{~h}$ in media supplemented with TH at 10\%, 20\% and 40\% (w/v). Error bars show SEM.) 
Vol. 11 No. 2:1 doi: $10.3823 / 856$ tion of $60 \%(P=0.03)$ was observed with $10 \%(\mathrm{w} / \mathrm{v})$ $\mathrm{TH} ; 20$ and $40 \%(\mathrm{w} / \mathrm{v}) \mathrm{TH}$ resulted in between $80 \%$ $(\mathrm{P}=0.02)$ and $86 \%(\mathrm{P}=0.01)$ reduction in biomass, respectively.

\section{Gene expression of S. pneumoniae following treatment with $\mathrm{TH}$}

As shown in Table $\mathbf{3}$ and Figure 3, we performed RT-qPCR on 13 differentially expressed genes of $S$. pneumoniae. We calculated the fold-changes in gene expressions after normalization of each gene relative to the constitutively expressed gene $g y r B$ after exposure to $\mathrm{TH}$ using the comparative threshold method (22).

Genes pnpA and purN encoding purine and pyrimidine nucleotide metabolism

Two genes (pnpA and purN) associated with ribonucleotide biosynthesis in $S$. pneumoniae biofilms were increased 1.8 fold and 2.2-fold in gene expression respectively after treated with $\mathrm{TH}$ as shown in Table 3.

\section{Genes mvaS and mvd1 encoding Isoprenoid metabolism}

The two important isoprenoid metabolism pathway genes (mvaS and mvd1) were up regulated in $S$. pneumoniae biofilms. The fold increase in gene expression was $4.5(P=0.04)$ and $3.3(P=0.01)$ respectively after exposure to $\mathrm{TH}$ as shown in Table $\mathbf{3}$.

\section{Genes ccpA and marR encoding transcription regulatory protein}

The two regulatory proteins encoding genes (cсpA and $m a r R$ ), were exclusively down regulated in biofilm. $\operatorname{cp} A$ and $\operatorname{mar} R$ were down regulated by more two-fold $(P<0.05)$ as shown in Table 3.

Table 3. Gene expression in S. pneumoniae biofilm after exposure to TH detected by RT-qPCR.

\begin{tabular}{|c|c|c|c|c|c|c|}
\hline \multirow{2}{*}{$\begin{array}{l}\text { Gene } \\
\text { name }\end{array}$} & \multirow{2}{*}{ Function } & \multirow{2}{*}{$\begin{array}{l}\text { Average } \\
\qquad \triangle \mathrm{Ct}\end{array}$} & \multirow{2}{*}{$\begin{array}{l}\text { Expression } \\
\text { Fold Change } \\
\qquad 2^{\wedge}-\Delta \Delta C t\end{array}$} & \multirow{2}{*}{$\begin{array}{l}\text { Expression Fold } \\
\text { Change } \\
\text { detected by real- } \\
\text { time RT-PCR }\end{array}$} & \multirow{2}{*}{ P-value } & \multirow{2}{*}{ SD } \\
\hline & & & & & & \\
\hline amiF & Protein transport & -1.00 & 2.00 & 2.0 & $0.03^{*}$ & 1.0 \\
\hline$f t s Y$ & $\begin{array}{l}\text { SRP-dependent cotranslational protein } \\
\text { targeting to membrane }\end{array}$ & -1.38 & 2.60 & 2.6 & $0.03^{*}$ & 0.6 \\
\hline mvas & Isoprenoid biosynthetic process & -2.17 & 4.50 & 4.5 & $0.04^{*}$ & 0.9 \\
\hline pnpA & RNA processing & -0.85 & 1.80 & 1.8 & $0.02 *$ & 0.7 \\
\hline $\arg G$ & Arginine biosynthetic process & -1.43 & 2.70 & 2.7 & $0.02 *$ & 0.8 \\
\hline mvd1 & Isoprenoid biosynthetic process & -1.72 & 3.30 & 3.3 & $0.01 *$ & 0.8 \\
\hline purN & 'de novo' IMP biosynthetic process & -1.14 & 2.20 & 2.2 & $0.01 *$ & 1.0 \\
\hline $\operatorname{mia} A$ & tRNA processing & -1.49 & 2.80 & 2.8 & $0.02 *$ & 1.0 \\
\hline pbp2a & Cellular wall organization & -1.38 & 2.60 & 2.6 & $0.03^{*}$ & 0.6 \\
\hline glck & Kinase activity & 1.20 & 0.43 & -2.3 & $0.02 *$ & 1.7 \\
\hline marR & $\begin{array}{l}\text { Sequence-specific DNA binding } \\
\text { transcription factor activity }\end{array}$ & 2.00 & 0.25 & -4.0 & $0.04^{*}$ & 2.0 \\
\hline prmA & Protein methyltransferase activity & 1.32 & 0.40 & -2.5 & $0.02^{*}$ & 1.7 \\
\hline ссрA & $\begin{array}{l}\text { Sequence-specific DNA binding } \\
\text { transcription factor activity }\end{array}$ & 1.43 & 0.37 & -2.7 & $0.01 *$ & 1.8 \\
\hline
\end{tabular}


Figure 3: Gene expression profile in S. pneumoniae after being treated with $\mathrm{TH}$.

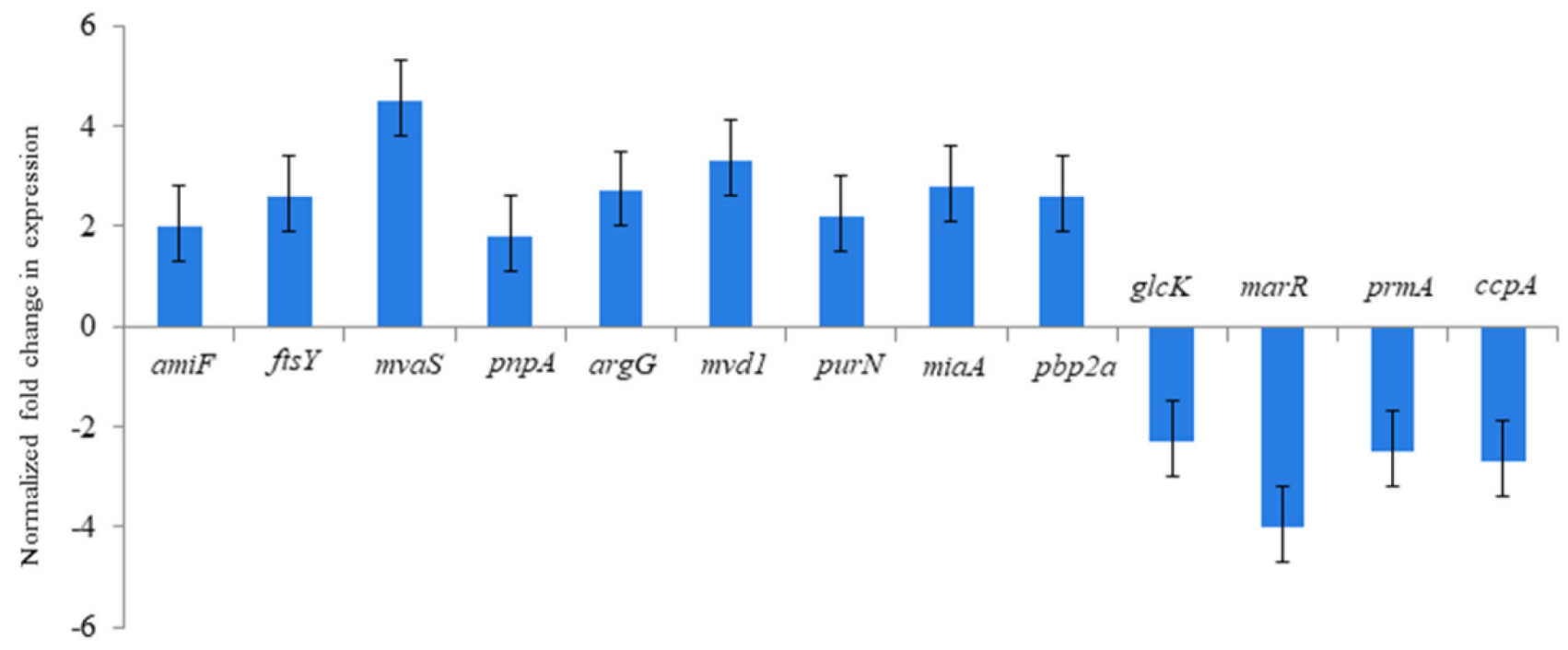

Genes

Genes amiF, fts, argG, pbp2a, glcK and prmA encoding Transporter proteins

Six genes amiF, ftsY, argG, pbp2a, glcK and prmA were differentially regulated in biofilms $S$. pneumoniae. All genes were up regulated in biofilms except g/cK and prmA were down regulated after exposure to $\mathrm{TH}$ as shown in Table 3 \& Figure 3.

\section{Discussion}

Antibacterial activity of honey has been broadly discussed among researchers worldwide. MIC is the lowest concentration of honey solution required to inhibit $99.9 \%$ of bacterial growth. MBC is defined as the lowest concentration of honey required to kill at least $99.9 \%$ of the tested bacterial strains [21]. Previous studies showed that MIC and MBC for Manuka honey, Kelulut honey, Egyptian clover honey and Algerian honey against Pseudomonas aeruginosa were at $20 \%$ and $25 \%$ concentration of honey respectively [21, 23, 27-28]. Study by Roberts et al., (2012) demonstrated that MIC and MBC for Manuka honey against $P$. aeruginosa were at $12 \%$ and $16 \%$ concentration of honey respectively [29]. According to results in disruption, the trend of all concentrations of $\mathrm{TH}$ had disrupted biofilm formation of S. pneumoniae, where the inhibition rate increased from $10 \%(\mathrm{w} / \mathrm{v})$ honey concentration until reached to honey concentration of $40 \%(\mathrm{w} / \mathrm{v})$. Previous studies demonstrated the ability of Manuka honey to disrupt preformed biofilms of $S$. pyogenes and $P$. aeruginosa $[24,29]$. A study by Hammond et al., (2014) demonstrated that a dose-response of Manuka honey was able to reduced biofilm biomass of Clostridium difficile strains and the optimum Manuka honey activity occurred at 40-50\% (v/v) [30]. A study by Eminek et al., (2017) showed that biofilms was developed over 3 days of $E$. coli and Proteus mirabilis culture and honey gave a dose-dependent reduction in biofilm formation (between 3.3 and $16.7 \% \mathrm{w} / \mathrm{v}$ ) [31]. A previous study reported that New Zealand, Cuba, and Kenya honeys were able to inhibit biofilm formation and to disrupt biofilms of $S$. aureus, $P$. aeruginosa and $S$. pyogenes [32]. The similarly or divergence of results might be due to several reasons such contain different level of active compounds including phenolic acids and flavonoids [17, 33-34].

RT-qPCR was used to determine the level of gene expression of $S$. pneumoniae after treated 
with $\mathrm{TH}$. The overall expression pattern demonstrated that more genes were up regulated in biofilm after exposure to $\mathrm{TH}$. The up regulation of peptidoglycan biosynthesis genes and ribosomal genes demonstrates that, in $S$. pneumoniae biofilm, cells are growing and may be involved in protein synthesis for various processes. The down regulation of ribosomal protein genes in biofilm cells indicates that free-floating S. pneumoniae has reduced transcription capacity [35]. In this study, we used TSB medium supplied with $5 \%$ glucose for biofilm growth with and without honey. Here, we detected up regulation of ribonucleotide biosynthesis genes (pnpA and purN) in biofilm cells. Streptococcus mutans, PnpA is reportedly up regulated under stress conditions such as acidic $\mathrm{pH}$, and is significant for cell viability and mRNA turn over in E. coli [36]. Our results suggest that biofilm cells are possibly under stress conditions and that stress-related genes are up regulated to support biosynthesis of new nucleic acid. The recent discovery that diphosphomevalonate, an intermediate in the mevalonate pathway, potently and allosterically down regulates the activity of $S$. pneumoniae mevalonate kinase without inhibiting the human enzyme [37] provides an opportunity for developing a new class of antimicrobials that are capable of killing this bacterium without detriment to the host. The finding of down regulation of three regulatory proteins encoding genes (ccpA, and marR) in biofilm cells after exposed to $\mathrm{TH}$. S. pneumoniae adapts to changing growth conditions through catabolite repression mediated by CсpA. In a previous study, СсpA was reported to be required for colonization of the nasopharynx and survival and multiplication in the lung [38]. MarR proteins regulate aromatic catabolism, expression of virulence factors and the response to antibiotic, antimicrobial stress and oxidative stress [39]. The transporter protein coding gene amiE are up regulated in biofilms after treated. The amiF encode oligopeptide $A B C$ transporters, whose ATP-binding protein domains function in competence. Similar up regulation of amiF gene in meningitis bacteria has been reported [35]. The up regulation of this competence and peptide transporter gene indicates that cells in biofilms may be involved in natural competence. Our study detected a few virulence and pathogenic genes whose expressions were up regulated and down regulated in in vitro early biofilms after adding honey. However, the gene expression patterns of most biofilm genes are close to previous gene expression reports in vivo [35] and in vitro [4]. This study reports a few genes that were down regulated to early in vitro biofilms after treatment with $\mathrm{TH}$. Moreover, many studies have demonstrated strain-specific gene regulation in $S$. pneumoniae [40-41], gene expressions differing with the richness of growth media, bacteria seeding, and strain capsulation, factors which affect biofilm formation on microtiter plates [42-43].

In summary, honey is a complex substance estimated to be comprised of between 200 and 600 components, including fructose, glucose, sucrose and other sugars [44]. Additional minor constituents include acids, proteins, amino acids, nitrogen, and minerals. The antibacterial action of $\mathrm{TH}$ is attributed to its high osmolarity, low water activity, viscosity, low PH and the presence of hydrogen peroxide. The combination of these factors is thought to provide an unsuitable environment for bacterial growth.

\section{Conclusion}

According our best knowledge, this is the first study investigated the level of gene expression of $S$. pneumoniae after exposure to $\mathrm{TH}$. We conclude that the exclusive up regulation and down regulation in genes involved in biofilms formation after treated with honey involved in the mevalonate pathway, cell wall biosynthesis, translation and purine and pyrimidine nucleotide metabolic pathway suggests that expression of these genes may be required for initial biofilm formation, and growth 
and survival of bacteria in biofilms. Our results indicate that the $\mathrm{TH}$ might be used for antibacterial agents for treatment and modulation of infections caused by S. pneumoniae.

\section{Acknowledgmen}

We thank all the staff members of the Faculty of Health Sciences and Microbiology Laboratory, Universiti Sultan Zainal Abidin for their support and commitment.

\section{Conflict of interests}

The authors declare that there is no conflict of interest regarding the publication of this article.

\section{References}

1. Feldman C, Anderson R. New insights into pneumococcal disease. Respirology. 2009; 14(2):167-79.

2. Kadioglu A, Weiser JN, Paton JC, Andrew PW. The role of Streptococcus pneumoniae virulence factors in host respiratory colonization and disease. Nat Rev Microbiol 2008; 6(4):288.

3. Bogaert D, de Groot R, Hermans P. Streptococcus pneumoniae colonisation: the key to pneumococcal disease. Lancet Infect Dis 2004; 4(3):144-54.

4. Oggioni MR, Trappetti C, Kadioglu A, Cassone M, lannelli F, Ricci $S$, et al. Switch from planktonic to sessile life: a major event in pneumococcal pathogenesis. Mol Microbiol 2006; 61(5):1196210.

5. Lizcano A, Chin T, Sauer K, Tuomanen El, Orihuela CJ. Early biofilm formation on microtiter plates is not correlated with the invasive disease potential of Streptococcus pneumoniae. Microb Pathog 2010; 48(3-4):124-30.

6. Dixon B. Bacteria can't resist honey. Lancet Infect Dis 2003; 3(2):116

7. Zumla A, Lulat A. Honey-a remedy rediscovered. SAGE Publ Sage UK: London, England; 1989.

8. Robson V, Dodd S, Thomas S. Standardized antibacterial honey (Medihoney ${ }^{\mathrm{TM}}$ ) with standard therapy in wound care: randomized clinical trial. J Adv Nurs 2009; 65(3):565-75.

9. Cooper R, Jenkins L, Henriques A, Duggan R, Burton N. Absence of bacterial resistance to medical-grade manuka honey. Eur J ClinMicrobiol Infect Dis 2010; 29(10):1237-41.

10. Molan P. Why honey is effective as a medicine: 2 . The scientific explanation of its effects. Bee world 2001; 82(1):22-40.
11. Estevinho L, Pereira AP, Moreira L, Dias LG, Pereira E. Antioxidant and antimicrobial effects of phenolic compounds extracts of Northeast Portugal honey. Food Chem Toxicol 2008; 46(12):3774-9.

12. Voidarou C, Alexopoulos A, Plessas S, Karapanou A, Mantzourani I, Stavropoulou E. Antibacterial activity of different honeys against pathogenic bacteria. Anaerobe 2011; 17(6):3759.

13. Lusby PE, Coombes AL, Wilkinson JM. Bactericidal activity of different honeys against pathogenic bacteria. Arch Med Res 2005; 36(5):464-7.

14. Biluca FC, Braghini F, Gonzaga LV, Costa ACO, Fett R. Physicochemical profiles, minerals and bioactive compounds of stingless bee honey (Meliponinae). J Food Compos Anal 2016; 50:61-9.

15. Rao PV, Krishnan KT, Salleh N, Gan SH. Biological and therapeutic effects of honey produced by honey bees and stingless bees: a comparative review. Rev Bras 2016; 26(5):657-64.

16. Brudzynski K. Effect of hydrogen peroxide on antibacterial activities of Canadian honeys. Can J Microbiol 2006; 52(12):122837.

17. Jibril FI, Hilmi ABM, Manivannan L. Isolation and characterization of polyphenols in natural honey for the treatment of human diseases. Bull Natl Res Cent 2019; 43(1):4.

18. Mshelia B. The antibacterial activity of honey and lemon juice against Streptococcus pneumoniae and Streptococcus pyogenes isolates from respiratory tract infections. Acta Sci Microbiol 2018; 1:22-7.

19. Al Kafaween MA, Hilmi ABM, Khan RS, Bouacha M, Amonov M. Effect of Trigona honey on Escherichia coli cell culture growth: In vitro study. J Apither. 2019; 5(2):10-7.

20. Hudzicki J. Kirby-Bauer disk diffusion susceptibility test protocol. American Society for Microbiology, 2009.

21. Zainol MI, Yusoff KM, Yusof MYM. Antibacterial activity of selected Malaysian honey. BMC 2013; 13(1):129.

22. Lye PY. Interactive effect of trigona honey and ampicillin on Staphylococcus aureus isolates of infected wound(Thesis Project,2015).Malaysian Main library, 30 Nov 2015 11:11

23. Bouacha M, Ayed H, Grara N. Honey Bee as Alternative Medicine to Treat Eleven Multidrug-Resistant Bacteria Causing Urinary Tract Infection during Pregnancy Sci Pharm 2018; 86(2):14.

24. Maddocks SE, Lopez MS, Rowlands RS, Cooper RA. Manuka honey inhibits the development of Streptococcus pyogenes biofilms and causes reduced expression of two fibronectin binding proteins. Microbios 2012; 158(3):781-90.

25. Al-kafaween MA, Hilmi ABM, Al-Jamal HAN, Elsahoryi NA, Jaffar N, Zahri MK. Pseudomonas Aeruginosa and Streptococcus Pyogenes Exposed to Malaysian Trigona Honey In Vitro Demonstrated Downregulation of Virulence Factor. Iran J Biotechnol 2020; 18(4):115-23. 
26. Mohammad A. Al-kafaween HANA-J, Abu Bakar Mohd Hilmi. Antibacterial activity of selected varieties of Malaysian honey against Escherichia coli: A comparative study. Int J Antimicrob Agents 2021; 11(1:3).

27. Abbas HA. Comparative antibacterial and antibiofilm activities of manuka honey and Egyptian clover honey. Asian J Appl Sci 2014; 2(02).

28. Shenoy VP, Ballal M, Shivananda P, Bairy I. Honey as an antimicrobial agent against Pseudomonas aeruginosa isolated from infected wounds. J Glob Infect Dis 2012; 4(2):102.

29. Roberts AE, Maddocks SE, Cooper RA. Manuka honey is bactericidal against Pseudomonas aeruginosa and results in differential expression of oprF and algD. Microbios 2012; 158(12):3005-13.

30. Hammond EN, Donkor ES, Brown CA. Biofilm formation of Clostridium difficile and susceptibility to Manuka Honey. BMC 2014; 14(1):329.

31. Emineke S, Cooper AJ, Fouch S, Birch BR, Lwaleed BA. Diluted honey inhibits biofilm formation: potential application in urinary catheter management? J Clin Pathol 2017; 70(2):140-4.

32. Morroni G, Alvarez-Suarez JM, Brenciani A, Simoni S, Fioriti S, Pugnaloni $A$, et al. Comparison of the antimicrobial activities of four honeys from three countries (New Zealand, Cuba, and Kenya). Front Microbiol 2018; 9:1378.

33. Alzahrani HA, Alsabehi R, Boukraâ L, Abdellah F, Bellik Y, Bakhotmah BA. Antibacterial and antioxidant potency of floral honeys from different botanical and geographical origins. Molecules 2012; 17(9):10540-9.

34. Moussa A, Noureddine D, Saad A, Abdelmalek M, Salima B. The influence of botanical origin and physico-chemical parameters on the antifungal activity of Algerian honey JPPM. 2015.

35. Orihuela CJ, Radin JN, Sublett JE, Gao G, Kaushal D, Tuomanen El. Microarray analysis of pneumococcal gene expression during invasive disease. Infect Immun 2004; 72(10):5582-96.

36. Len AC, Harty DW, Jacques NA. Stress-responsive proteins are upregulated in Streptococcus mutans during acid tolerance. Microbios 2004; 150(5):1339-51.

37. Barta ML, Skaff DA, McWhorter WJ, Herdendorf TJ, Miziorko HM, Geisbrecht BV. Crystal structures of Staphylococcus epidermidis mevalonate diphosphate decarboxylase bound to inhibitory analogs reveal new insight into substrate binding and catalysis. J Biol Chem 2011; 286(27):23900-10.

38. Iyer R, Baliga NS, Camilli A. Catabolite control protein A (CcpA) contributes to virulence and regulation of sugar metabolism in Streptococcus pneumoniae. J Bacteriol 2005; 187(24):8340-9.

39. Ellison DW, Miller VL. Regulation of virulence by members of the MarR/SlyA family. Curr Opin Microbiol 2006; 9(2):153-9.
40. Song X-M, Connor W, Jalal S, Hokamp K, Potter AA. Microarray analysis of Streptococcus pneumoniae gene expression changes to human lung epithelial cells. Can J Microbiol 2008; 54(3):189200.

41. Hendriksen WT, Silva N, Bootsma HJ, Blue CE, Paterson GK, Kerr AR, et al. Regulation of gene expression in Streptococcus pneumoniae by response regulator 09 is strain dependent. J Bacteriol 2007; 189(4):1382-9.

42. Hall-Stoodley L, Nistico L, Sambanthamoorthy K, Dice B, Nguyen D, Mershon WJ, et al. Characterization of biofilm matrix, degradation by DNase treatment and evidence of capsule downregulation in Streptococcus pneumoniae clinical isolates. BMC 2008; 8(1):173.

43. Allegrucci M, Sauer K. Characterization of colony morphology variants isolated from Streptococcus pneumoniae biofilms. J Bacteriol. 2007; 189(5):2030-8.

44. Bogdanov S, Vit P, Kilchenmann V. Sugar profiles and conductivity of stingless bee honeys from Venezuela. Apidologie 1996; 27(6):445-50.

\section{Publish in The International Arabic Journal of Antimicrobial Agents}

The Journal is an open access peer-reviewed journal that publishes scientific papers about all aspects of antimicrobials. The journal will publish original research articles, reviews, brief reports and case reports dealing with basic and clinical antibacterial agents, antiviral, antiprotozoals, antituberculuous, antifungal and antihelminthes agents. All manuscripts must be prepared in English, and are subject to a rigorous and fair peer-review process. Accepted papers will immediately appear online. The journal aims to advance the knowledge, attitude and the research of chemotherapy in the Arabic world in cooperation with international, national scientific and public societies as well as research centers with similar aims and objectives. 